\title{
Management and marketing of private basketball clubs for children and juniors
}

\author{
Silvia GRĂDINARU ${ }^{1}$
}

\begin{abstract}
Basketball is in the top of favourite sports. The appearance of private sport clubs on the sports market is caused by the increasingly precarious conditions in state institutions and, at the same time, by the influence of the European Community. We aim at identifying a pattern of activity meant to attract and educated children in the field of basketball through private basketball clubs by making parents aware of the beneficial effects of basketball and of being a member of a sports team. The survey was carried out in 12 private basketball clubs that carry out activities in a consequent manner (in number and in value). Private basketball club managers responded to the questions in our questionnaire showing willingness to cooperate; results show that all private basketball clubs are non-profit organisations and are involved in the competitions organised by the Romanian Federation of Basketball. Private basketball clubs represent half of the affiliated basketball clubs and dominate the competitions reserved to the different age categories, which denotes the efficiency of their activities.
\end{abstract}

Keywords: management, marketing, efficiency, strategic plan, communication, social skills

\section{Rezumat}

Baschetul este în top ca popularitate. Apariția cluburilor private pe piața educațional-sportivă se datorează condițiilor tot mai precare din punct de vedere material a instituțiilor statului și în același timp și influențelor Comunității Europene.Urmărim identificarea unui model de atragere și instruire a copiilor în baschet în vederea eficientizării unui club privat și implicit conștientizare familiei în privința efectelor benefice ale practicării jocului de baschet și integrări copiilor în colectiv. Ancheta s-a desfășurat la 12 cluburi sportive de baschet în regim privat care desfășoară o activitate consecventă din punct de vedere numeric și valoric. Managerii cluburilor au răspuns la întrebările chestionarului manifestând disponibilitate de colaborare, iar în urma prelucrării datelor a rezultat că toate cluburile avute în studio au formă juridică non-profit și sunt angrenate în competițiile organizate de Federația Română de Baschet.Cluburile private reprezintă aproape jumătate dintre cluburile afilite și domină competițiile rezervate diferitelor categorii de vârstă ce denotă o eficiență a activității acestora.

Cuvinte cheie: management, marketing, eficacitate, plan strategic, comunicare, abilități sociale

\footnotetext{
${ }^{1} \mathrm{PhD}$ student, West University of Timișoara, Romania, e-mail: gradinarusilvi@gmail.com
} 


\section{Introduction}

The necessity of intensifying physical education and sports activities is unanimously acknowledged nowadays when, besides considerable advantages, modern, civilised life has brought about the danger of physical involution of humankind because of the lack of physical efforts.

In these conditions, practicing different forms of physical exercise - among which sports and sport games - is the main means of controlling and preventing the negative effects of modern living.

Practicing collective sport games cumulates the positive influences and effects of sports and the educational influences and effects of game. [1, 2] The appearance of private sport clubs on the sports market is caused by the increasingly precarious conditions in state institutions and, at the same time, by the influence of the European Community. In public teams, the number of athletes is limited and there is a single team for each age range; in addition, their components are very carefully selected.

The appearance of private sports clubs on the educational sports market has been welcome as an alternative for those that have not been included in these teams.

These private sports clubs have been established to provide initiation, formation, and preparation sessions in basketball. Children benefit from the opportunity of developing basic game skills and everyday behavioural skills in an attractive, wellorganised environment. There is a slight increase of the number of private sports clubs at national level.

\section{Goal of the Paper}

The paper aims at making families aware of the beneficial effects of practicing basketball and of integrating children in teams.

We would also like to identify some ways of attracting and educating children in a private basketball club.

\section{Hypotheses of the Paper:}

Proper management and marketing increase interest in children and meet their need for movement in an organised setting.

Private basketball clubs' efficiency reflects in the results in the competitions organised for the different age categories at national level.
All sports organisations have a well-determined goal and they act accordingly.

The goals of a sports organisation can have the following functions:

First, the objectives are theoretical statements that state the goal and provide an abstract of the activity of a sports organisation;

Second, the objectives provide guidance directions for the managers and other employees in certain fields of activity such as decisionmaking, assessing performance, designing activities, reducing uncertainty, managing and motivating employees, establishing legitimacy.

Preparing the athletes, ensuring the material conditions for exercising and participating in contests, activities meant to reach the different goals of a sports organisation needs planning activity per compartments, teams, athletes, coaches, different employees, etc. This also covers the design of activities in accordance with objectives, the timely preventing of intermediary and final results. Planning per se is a cybernetic process using cybernetic concepts in the athletes' preparation activities. [3, 4]

The world of business prospers through sports using it as a promotional vehicle. The capacity of sports of supporting its promotion expenses by partners associated through sponsorship, advertising or partnership promotion (e.g., mutual trading or barter of services) differs from that of any other sector of economy. $[5,6]$

\section{Material and Method}

The method used consisted in using a questionnaire meant to produce research data.

The questionnaire method consists in filling in a questionnaire with responses to questions. In the sports field, they use questionnaires with questions specific to sports activities and to athlete behaviour during the training or competitions.

We designed a direct questionnaire that we applied individually as a printed form.

The questionnaire consisted in 13 questions (close, open, and choice) that we present in the annex.

The questionnaire was applied in the competition year 2012-2013 and it focused on 12 private 
basketball clubs that are actively consistent in numbers and value.

In Romania, the specialised forum that coordinates basketball activities is the Romanian Federation of Basketball.

People practicing basketball: 36,600.

Owning a member's card: 17,400.

National championships: 22, of which 11 for men and 11 for women.

Affiliated basketball clubs: 237, of which 112 private basketball clubs.

The private basketball clubs aimed at by our survey were:

A.C.S. CHAMPIONS BUCUREŞTI;

A.S. BASCHET CLUB VALBON ARAD;

A.S. SOLARIS SPORTING CLUB PLOIEŞTI;

ASOCIAŢIA BASCHET CLUB BAIA MARE;

B.C. GALACTICA BRAŞOV;

C.S. GIANTS DEVA;

C.S. SPIKE BUCUREŞTI;

C.S. SPORT STAR TIMIŞOARA;

C.S. VEST ACTIV TIMIŞOARA;

M.C. SPORT CLUJ-NAPOCA;

M.P. SPORT TIMIŞOARA;

U-MOBITELCO CLUJ-NAPOCA.
As far as the preparation level is concerned, only $8.33 \%$ of the respondents work at all age levels, while $75 \%$ work at "Baby" level (up to 10 years), $83.33 \%$ work at "Mini" level (up to 12 years), and $75 \%$ work at junior level (13-18 years)(Figure 1).

We see that $75 \%$ of the studied private basketball clubs participate in local and international competitions, while $91.66 \%$ of them are involved in national competitions organised by the specialised federation (Figure 2).

The responses to the question "Do you organise coaching camps? In summer, winter or both seasons?" show that all private basketball clubs organise preparation camps in summer and only half of them organise them both in summer and winter (Figure 3).

The responses to the question "Is your private basketball club sponsored? If so, by whom? Private or local town hall/council?" show that private basketball clubs are $100 \%$ supported from the monthly fees, $75 \%$ benefit from private sponsorship, and only $25 \%$ benefit from local authorities' funds (Figure 4).
Figure 1. Preparation level

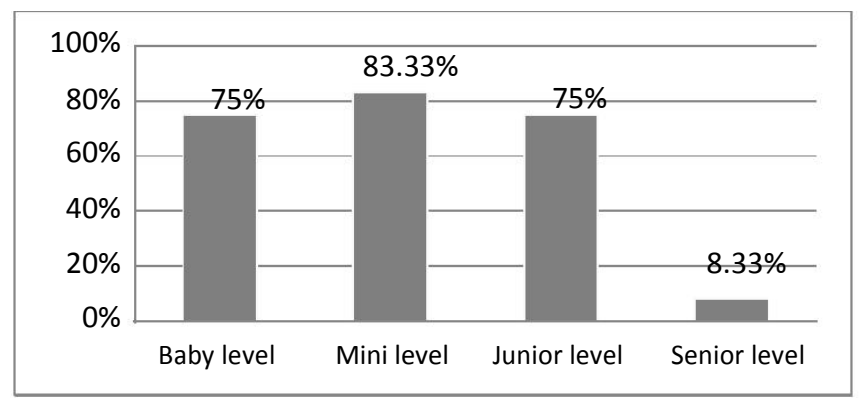

Figure 2. Basketball competitions your private basketball club takes part in

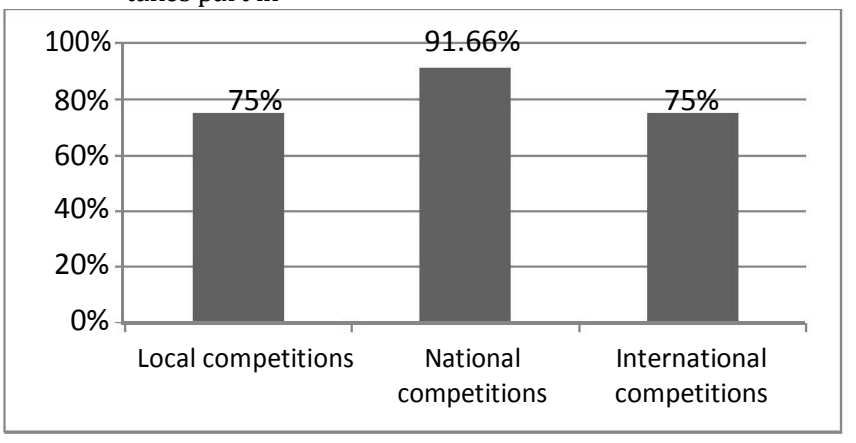

Figure 3. Periods when the private basketball organise preparation camps

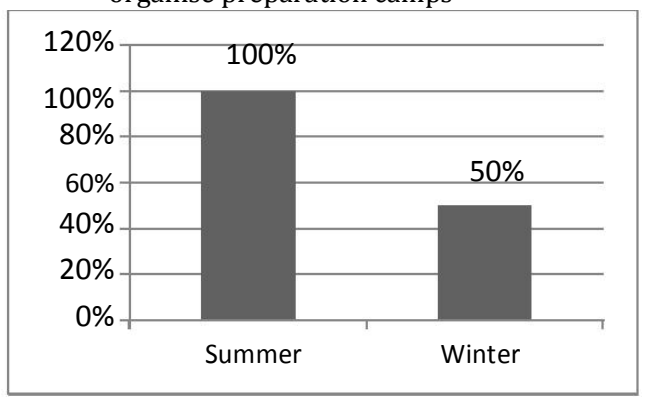

Figure 4. Sponsorship sources

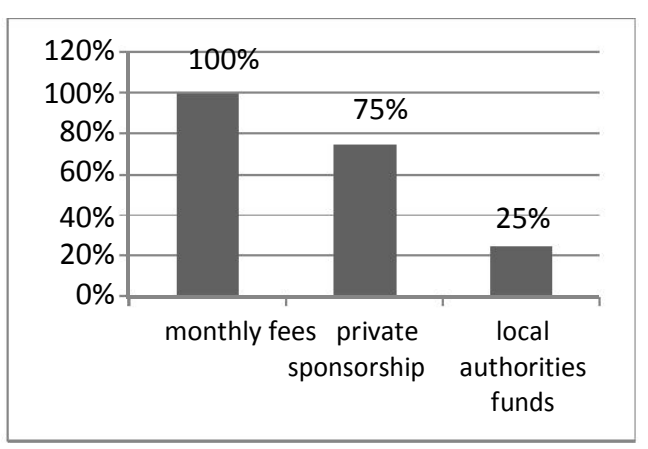


As for the question, "How many children are there in your private basketball club?" responses show that $75 \%$ of the private basketball clubs have up to 100 children and $25 \%$ have over 150 children (Figure 5).

Figure 5. Number of children per private basketball clubs

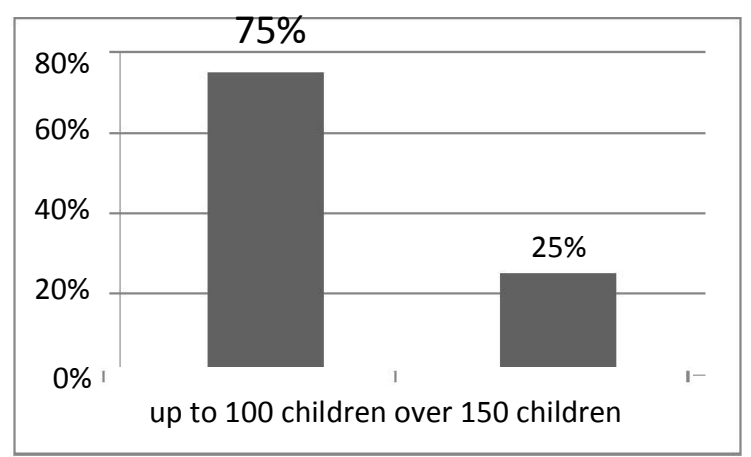

\section{Conclusions}

1. Students, from small school age to high school, are the focus of private basketball clubs.

2. All private basketball clubs are non-profit organisations.

3. All private basketball clubs participate in the competitions organised by the Romanian Federation of Basketball.

4. Private basketball club coaches participate on a regular basis in training courses organised by the Romanian Federation of Basketball.

5. Private basketball club budgets are confidential, most respondents avoiding to supply such information.

6. Private basketball clubs represent almost half of the basketball clubs affiliated with the Romanian Federation of Basketball.

7. Basketball competition reserved to the different age categories at national level are dominated by private basketball clubs, which shows the efficiency of their activity.
As far as the way the private basketball clubs are promoted, responses show that $85.33 \%$ of the respondents promote their activities through the Internet, $50 \%$ rely on promotional items, and only $8.33 \%$ rely on the media (Figure 6).

Figure 6. Ways of promoting private basketball clubs

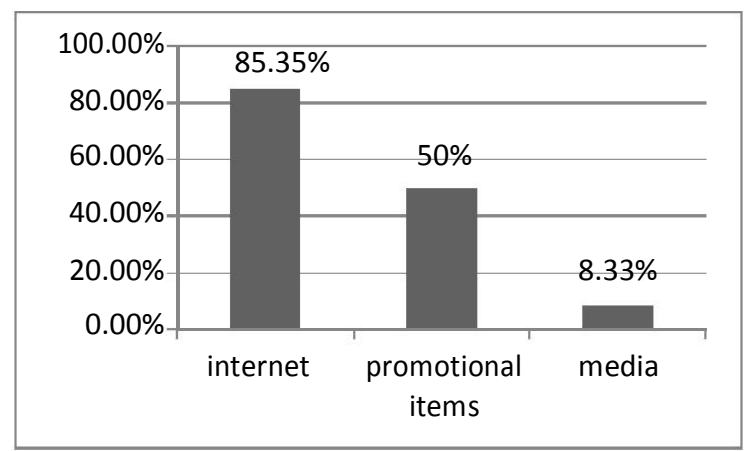

\section{Recommendations}

1. Private basketball club managers should be very demanding towards the coaches employed for preparing the athletes;

2. Promoting the activity of private basketball activities should be done mainly in schools to meet the need for moving in an organised environment;

3. Private basketball club managers should focus more on advertising their activities in the media.

\section{References}

1. Predescu T., Jianu E., Grădinaru Cs., Grădinaru S. (2010) Jocurile sportive în şcoală. Baschet-Fotbal-Handbal-Volei. Editura Politehnica, Timișoara.

2. Predescu T., Moanţă A. (2001) Baschetul în şcoală.InstruireÎnvăţare. Editura SemnE, Bucureşti.

3. Voicu S.F. (2002) Managementul sportului. Editura MIRTON, Timişoara.

4. Voicu S.F., Nagel A. (2003) Introducere în managementul şilegislaţia sportului. Editura Universităţii de Vest,Timişoara.

5. Oprișan V. (2001) Marketing şi comunicare în sport. Editura URANUS, București.

6. Negruţ C., Dobre C., Negruţ C. (1997) Iniţiere în marketing. Editura Augusta, Timişoara. 